\title{
En attendant Le Peletier de Saint-Fargeau: la règle pénale au début de la Révolution
}

\section{Roberto Martucci}

\section{Q OpenEdition \\ 12 Journals}

\section{Édition électronique}

URL : https://journals.openedition.org/ahrf/610

DOI : 10.4000/ahrf.610

ISSN : 1952-403X

Éditeur :

Armand Colin, Société des études robespierristes

Édition imprimée

Date de publication : 1 juin 2002

Pagination : 77-104

ISSN : 0003-4436

\section{Référence électronique}

Roberto Martucci, «En attendant Le Peletier de Saint-Fargeau: la règle pénale au début de la Révolution », Annales historiques de la Révolution française [En ligne], 328 | avril-juin 2002, mis en ligne le 20 avril 2004, consulté le 24 avril 2022. URL : http://journals.openedition.org/ahrf/610 ; DOI : https://doi.org/10.4000/ahrf.610

Ce document a été généré automatiquement le 24 avril 2022.

Tous droits réservés 


\title{
En attendant Le Peletier de Saint- Fargeau: la règle pénale au début de la Révolution
}

\author{
Roberto Martucci
}

\section{RÉSUMÉS}

Le code pénal Saint-Fargeau est l'aboutissement d'un long processus réformateur visant à contrecarrer l'hypothèse d'une codification du principe de lèse-Nation qui aurait frappé de la peine de mort une conduite «déviante» indéfinie. Les protagonistes de la stratégie codificatoire constituante furent les députés-juristes (Beaumetz, Du Port, Le Peletier de Saint-Fargeau) élus dans le Comité de Jurisprudence criminelle de l'Assemblée nationale. Le produit normatif de leur activité fut, d'abord, le vote des articles VII, VIII et IX de la Déclaration des droits qui constitutionnalisa le principe de stricte légalité; ensuite, l'introduction du rite mixte (décret des 8 et 9 octobre 1789). D'ailleurs, après l'adoption du jury criminel (printemps 1790) il devint urgent de voter à la fois une loi de procédure devant les jurés et un code pénal établissant un système de peines fixes.

Awaiting Le Peletier de Saint-Fargeau: Penal Provisions in the Early Days of the Revolution The Saint-Fargeau Penal Code was the result of a long reform process aimed at counteracting a hypothetical code which would have imposed the death penalty on undefined deviant conduct charged as high treason. The protagonists of this strategy of constitutional codification were the jurist-deputies (Beaumetz, Du Port, Le Peletier de Saint-Fargeau) who were selected to serve on the Criminal Jurisprudence Committee of the National Assembly. The normative product of their efforts was, above all, votes on Articles VII, VIII and IX of the Declaration of Rights, constitutionally guaranteeing the principle of strict equality. This was followed by the decree of 8 
\& 9 October 1789 which introduced rite mixte . Moreover, after the adoption of the right to a jury in a criminal trial (Spring 1790), the Committee took it as a matter of urgency to vote a law establishing proceedures in jury trials and a penal code which laid out a system of fixed penalties.

INDEX

Mots-clés : codification criminelle, légalité des délits et des peines, lèse-Nation, constituante, comité de jurisprudence criminelle 